\title{
The human impact imprint on modern pollen spectra of the Maya lands
}

Felipe Franco-Gaviria, Dayenari Caballero-Rodríguez, Alexander Correa-Metrio, Liseth Pérez, Antje Schwalb, Sergio Cohuo, Laura Macario-González

Felipe Franco-Gaviria

iffranco@comunidad.unam.mx

Dayenari Caballero-Rodríguez

Posgrado en Ciencias de la Tierra, Universidad

Nacional Autónoma de México,

Coyoacán, Ciudad de México, México 04510.

\section{Alexander Correa-Metrio}

Liseth Pérez

Instituto de Geología, Universidad Nacional Autónoma de México, Coyoacán, Ciudad de

México, México 04510.

\section{Antje Schwalb \\ Sergio Cohuo \\ Laura Macario-Gonzalez}

Institut für Geosysteme und Bioindikation, Technische Universität Braunschweig, Langer Kamp 19c, Germany 38106.

\begin{abstract}
To understand human occupation in the context of paleoecological records from the Maya region, there is need to explore the distribution of modern pollen along climate and human-impact gradients. In this study, we analyze the responses of pollen assemblages from 125 surface samples to human influence in the Maya region, using three basic approaches: (i) the evaluation of using modern pollen spectra to distinguish the main anthropogenic and natural vegetation types; (ii) the usage of detrended correspondence analysis (DCA) to evaluate the distribution patterns of pollen along environmental gradients including human influence; and (iii) the evaluation of the responses of taxon-specific elements to the human-influence gradient, that expresses on the modern landscape, using threshold-indicator taxa analysis. The 125 locations where mud-water interface samples were retrieved were divided into four groups that correspond to the major vegetation types of the Maya region (coniferous and Quercus forest, croplands and pastures, tropical seasonal forest, and tropical evergreen forest). In terms of individual taxa responses, we detected 20 elements significantly related to the human-influence gradient. These were assigned to negative (decreasing) or positive (increasing) response groups depending on the response direction. Mostly arboreal elements from tropical seasonal forests decreased, while non-arboreal elements typically from anthropogenic vegetation increased in response to different levels of human influence. Also, a community-level abrupt point change is detected at a human influence index of 15 . When human influence exceeds this threshold, important elements of the natural vegetation are negatively affected while opportunistic elements become favored. Overall, the study of pollen distribution along environmental gradients and the identification of taxa indicators of human impact provide valuable tools for the interpretation of fossil pollen records from the Maya region.
\end{abstract}

VOL. 70 NO.

P. $61-78$

http://dx.doi.org/10.18268/BSGM2018v70nla4

Manuscript received: December 1, 2016. Corrected manuscript received: May 5, 2017.

Manuscript accepted: May 25, 2017.
Keywords: Anthropogenic and natural vegetation, Human Influence Index (HII), modern pollen, threshold-indicator taxa analysis, Maya lands.

\section{RESUMEN}

Para entender el registro paleoecológico en el contexto de la ocupación humana, es necesario examinar la distribución del polen moderno a lo largo de gradientes climáticos $y$ de impacto humano. Este estudio analiza las respuestas de ensambles de polen moderno de 125 muestras superficiales a la influencia humana de la región Maya, usando tres aproximaciones básicas: i) evaluación de la habilidad de espectros de polen moderno para distinguir los principales tipos de vegetación antropogénica y natural, ii) uso del análisis de correspondencia sin tendencia (DCA por sus siglas en ingles) para evaluar los patrones de distribución del polen a lo largo de gradientes ambientales que incluyen la influencia humana, y iii) evaluación de las respuestas de taxa individuales a un gradiente de influencia humana a través del análisis de taxa indicadores de umbral. Las 125 muestras de la interfaz agua-sedimento se dividieron en cuatro grupos que corresponden a los principales tipos de vegetación de la región Maya (bosque de pino-encino, cultivos y pastizales, bosque estacional tropical, y bosque tropical siempre verde). En términos de las respuestas a nivel de taxón, nosotros detectamos 20 elementos asociados significativamente con el gradiente de influencia humana. Estos elementos fueron asignados a grupos de respuesta negativos (disminuciones) o positivos (incrementos) dependiendo de la dirección de respuesta. La mayoría de los elementos arbóreos de bosques estacionales tropicales disminuyeron, mientras elementos no-arbóreos típicamente de vegetación antrópica aumentaron en respuesta a diferentes niveles de influencia humana. Adicionalmente, fue detectado un cambio abrupto a nivel de comunidad para un índice de influencia humana de 15. Cuando la influencia humana supera este umbral, elementos importantes de la vegetación natural son afectados negativamente, mientras elementos oportunistas son favorecidos. En general, el estudio de la distribución del polen a lo largo de gradientes ambientales, así como la identificación de taxa indicadores de impacto humano, ofrecen herramientas valiosas para interpretar los registros de polen fósil de la región Maya.

Palabras clave: Vegetación antropogénica y natural, Índice de Influencia Humana (HII), polen moderno, análisis de taxa indicadores de umbrales, tierras mayas. 


\section{Introduction}

Over millennia, humans have adapted to environmental changes in a variety of ways, causing substantial transformation of the lands they occupy (Dearing, 2006). In Mesoamerica, transformations of natural environments have been a common feature at least since the mid Holocene, and have manifested mostly through the exploitation of wild plants and the establishment of crops (Palka, 2009). It is expected that human activities and occupation of the landscape would follow the complexities of the environmental mosaic with differential focus on regions where environmental conditions are more suitable for human settlement and occupation. However, paleoecological and archaeological evidence suggest human occupation has not only been the result of physical geography, but there have also been historic and societal components (Leyden, 1987; Sharer and Traxler, 2006). Mesoamerica has been home to the Maya civilization for more than 4000 years (Sharer and Traxler, 2006). The most readily recognized aspects of this culture are its large urban centers and extensive agricultural systems, two features that strongly impacted the territory in the Maya region (Beach et al., 2006; Piperno, 2006). This intense human-environment interaction has taken place through the Late Holocene. Understanding how human activities have modified the environment at different spatial and temporal scales provides important insights to the understanding of the environmental system and how it evolves under the influence of human populations.

Pollen analysis has been widely used for reconstructing past changes in vegetation and their associated drivers (Delcourt and Delcourt, 1991). In the Maya region, modern pollen assemblages represent current parental vegetation and the underlying environmental gradients (Correa-Metrio et al., 2011). However, our ability to understand the nature and extent of past human impacts on vegetation based on pollen relies on identifying key indicator taxa from modern pollen associations. In pollen assemblages from the Maya lands, the clearest signal for human influence or impact would be the presence of cereals (e.g., Zea mays, primary indicators sensu Piperno, 1998), manioc (Manihot esculenta), and squash (Cucurbita sp.). However, synanthropic plants growing on farmlands and disturbed sites are also detected in the pollen spectrum, although the scope as environmental indicators remains unclear. Maya communities have been characterized by adopting agroforestry systems (the Maya Milpa) involving the management of some trees and non-arboreal elements (Nigh and Diemont, 2013). Thus, taxa favored by the spread of human activities would be particularly useful for reconstructing vegetation changes associated with forest management, agricultural activity, and their effects on natural ecosystems (Brun, 2011). By analyzing modern pollen assemblages in terms of human influence, we aim to establish a basis to better assess human-induced landscapes using fossil pollen records. Study of the pollen signal of human activities would benefit from selecting those groups with a distinctive response to the human impact.

In this study, we evaluate the sensitivity of modern pollen assemblages to human impact at community and taxon level. To assess human impact, we used the modern global data set of Human Influence Index (HII, Sanderson et al., 2002), a spatial product that provides an assessment of the level of anthropogenic influence on the landscape. The index integrates human population density, degree of land transformation, accessibility, and power infrastructure into an index that can be estimated for any given region. Characterizing the relationship between pollen assemblages and HII allows the identification of potential pollen indicators for human impact. We hypothesize that individual taxa and assemblages would show strong relationships with the HII and would exhibit sharp, nonlinear responses as thresholds at certain levels of landscape alteration. Thus, the main objectives of this study are: first, to assess whether pollen assemblages respond to human influence determined by the HII; second, to identify potential indicator pollen taxa of human influence; and third, to analyze 
patterns of changes at the community level and the possible existence of critical thresholds in the vegetation along the human-influence gradient.

\section{Material and Methods}

\subsection{STUDY AREA}

The study area is located in the zone culturally delimited as Maya region, roughly between 13.30 to $21.40 \mathrm{~N}$ and from 87.10 to $93.80 \mathrm{~W}$ (Figure 1), spanning from the lower Lempa River in El Salvador to the Isthmus of Tehuantepec in Mexico, and covering about $324000 \mathrm{~km}^{2}$ of tropical lands. The region could be roughly divided into three main geographical zones: (i) the southern highlands that include the mountains of Honduras, Guatemala, and Chiapas; (ii) the southern lowlands that cover Petén in northern Guatemala, northern
Honduras, Belize, and the southern portions of Yucatan Peninsula; and (iii) the northern lowlands on the central and northern portion of Yucatan Peninsula.

The Climate is warm in the lowlands and becomes cooler towards the highlands, with differences among regions mostly produced by rainfall patterns. High topographic diversity expressed through large elevations gradients and rain shadows lead to significant precipitation variability across the region. In the highlands and the mountains annual precipitation can reach up to 5000 $\mathrm{mm}$, while in northwestern Yucatan it barely reaches $500 \mathrm{~mm}$ (Méndez and Magaña, 2010). The climate is primarily controlled by the atmospheric patterns influenced by the Intertropical Convergence Zone and the Bermuda High, which together cause a markedly wet season from May to November, and a dry season from December to May (Wilson, 1980; Magaña et al., 2003).
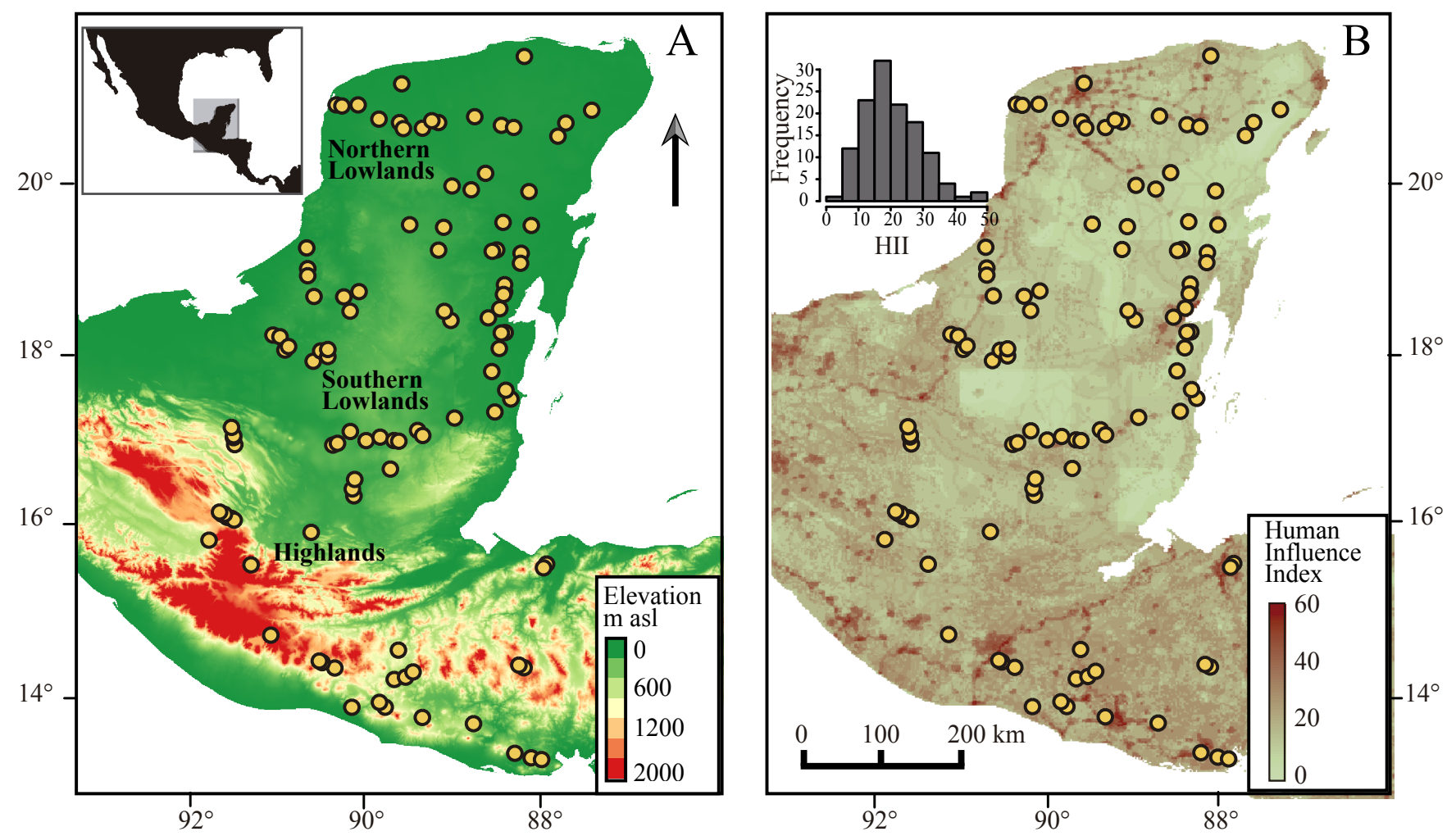

Figure 1 Study area. A. Elevation map indicating the main geographical zones in the Maya region, and B. Human Influence Index (HII) along the region with their respective frequencies. Yellow dots show the location of the sampled lakes (see Appendix 1 for a list of samples and their geographic coordinates). 
Temperature and precipitation are the main drivers of natural vegetation patterns across the Maya lands, whereas precipitation seasonality and edaphic features exert a more local control on vegetation associations. Scrubs and tropical deciduous forests naturally cover the northernmost and driest portion of the Yucatan Peninsula, whereas tropical semi-deciduous forests dominate the central and northeast areas, where conditions are still dry but less seasonal. As precipitation rises southward, tropical evergreen forest emerge, with intermissions of woody savannas around Belize and northern Guatemala, commonly associated with local edaphic conditions (Rzedowski, 2006). The highland mountains are characterized by three basic types of vegetation, namely mountain mesophyllous forest, Quercus forest, and coniferous forest (Nixon, 2006; Rzedowski, 2006).

Human impact has caused important changes in the natural vegetation mostly through deforestation. These changes have favored a widespread distribution of human-induced vegetation characterized manly by croplands and pastures in the entire region (Loveland et al., 2000; Rzedowski, 2006). Anthropogenic vegetation in Mesoamerica is the result of both modern land uses and at least five millennia of extensive human occupation (Pohl et al., 1996). The earliest cultivation of maize and the associated impact on vegetation have been reported between 5000 and 4500 years ago in Belize and Guatemala (Pohl et al., 1996; Piperno, 2006; Wahl et al., 2006). Crops of diverse sizes included maize (Zea mays), beans (Phaseolus spp.), squash (Cucurbita sp.), and papaya (Carica papaya). Also, the ancient legacy of Mayan agroforestry has been in use for 4000 years and it is widespread among present-day farmers. These activities include the Maya milpa that consists of annual rotation of crops with a series of managed arboreal species (e.g., Brosimum alicastrum, Bursera simaruba, Cecropia peltata, and Zwietenia macrophylla), which under abandonment lead to their dominance in the reestablished forest (Quintana-Ascencio et al., 1996; Ford and Nigh, 2009; Nigh and Diemont, 2013). Besides the previously mentioned species, in the Maya milpa, species such as Acacia cornigera, Brosimum alicastrum, Bursera simaruba, Cecropia peltata, Zwietenia macrophylla, and Vitex gaumeri are also commonly found (Ford and Nigh, 2009). Currently, new production systems such as cattle raising and other crops (e.g., sugarcane and coffee) are also widespread along the region (Sharer and Traxler, 2006).

\subsection{POLLEN AND HUMAN INFLUENCE DATA SET}

The pollen data set was composed of modern sediment samples collected along the Maya region. Whereas part of the dataset came from previously published work (77 samples from the Yucatan Peninsula and adjacent mountains, Correa-Metrio et al., 2011), 48 new samples were collected, extending the sampling towards Guatemala, Honduras and Salvador (Appendix 1). The preparation and analysis of the new samples followed the protocols described by Correa-Metrio et al. (2011) to ensure homogeneity of the entire dataset. All pollen counts were transformed to percentages of the pollen sum to off set differences in sample size (Birks and Gordon, 1985).

Human influence at the sampled sites was assessed using the global Human Influence Index (HII) dataset, which has a spatial resolution of $1 \mathrm{~km}^{2}$ (Sanderson et al., 2002). HII values range from zero for fully pristine areas, to 64 for totally urbanized regions (for details see Sanderson et al., 2002, and http://sedac.ciesin.columbia.edu/data/set/ wildareas-v2-human-footprint-geographic).

\subsection{DATA ANALYSIS}

A Detrended Correspondence Analysis (DCA, Hill and Gauch, 1980) on the pollen dataset was used to explore the ability of pollen assemblages to reflect human-impact patterns at the community level. The DCA was meant to identify the ecological space represented by the pollen samples through the a priori interpretation of taxa ordination (Correa-Metrio et al., 2014). HII values per taxon were calculated though averages of HII of the sites weighted by taxon-relative abundance. 
Subsequently, HII per species and sites were compared with DCA taxa and sites' scores, respectively, and their relationship was generalized thorough non-parametric locally weighted regression (Cleveland and Devlin, 1988).

Given oversampling of some localities within the studied region, the original dataset was geographically resampled, using a 2x2 km grid, where only one sample was selected from each cell. The resampling was replicated 500 times. Additionally, the resampled dataset was submitted to a filter to avoid undesirable effects of rare species (only taxa with a minimum abundance of $1 \%$ in $5 \%$ of the samples were selected, after Correa-Metrio et al., 2010).

The magnitude, direction, and uncertainty of responses of individual taxa and community to the studied human-influence gradient were estimated though a Threshold Indicator Taxa Analysis (Baker and King, 2010). The method finds values along the studied environmental gradient (HII in this case) where the largest community change occurs. An indicator value is calculated for each taxon at each candidate change-point along the human-impact gradient, and change-points with maximum indicator values are retained (for details see Dufrene and Legendre, 1997). Scores of the indicator values are subsequently standardized to obtain a Z-score for each taxon, such that positive and negative responses can be distinguished (Baker and King, 2010). Community-level thresholds can be estimated as the summation of individual taxon responses represented by $\mathrm{Z}$-scores. A bootstrap resampling is performed to evaluate statistical significance of Z-scores, which can be summarized as follows: (i) high purity when the $\mathrm{Z}$-scores associated with the taxon are found within the same segment and show the same direction in at least $90 \%$ of the bootstrapping runs (1000 in total), and (ii) high reliability when at least $95 \%$ of bootstrapping were significantly different from a random distribution $(\mathrm{p}<0.05)$. All analyses were performed using $\mathrm{R}$ (R Core Team, 2017), especially packages TITAN 2.0 (Baker and King, 2013) and Vegan 2.4 (Oksanen et al., 2017).

\section{Results}

\subsection{POLLEN ASSEMBLAGES AND HUMAN INFLUENGE INDEX AT THE MAYA LANDS}

With an average pollen count of 427 grains per sample, the 125 samples totaled 192 pollen taxa. The different kinds of highlands formations (mountain mesophyllous forest, Quercus forest, and coniferous forest) do not display a particular pollen signature. Therefore, the samples of these locations are grouped together as coniferous-Quercus forest $(\mathrm{CQF})$. These samples are located at elevations above 1400 m a.s.l. (e.g., Atitlán, Chilangatorio, Esmeralda, and 5-Lakes) and show high percentages of Pinus, Quercus, Liquidambar, and Myrica (Figure 2). Croplands and pastures (CP) are characterized by a dominance of non-arboreal pollen (e.g., Amaranthaceae, Byrsonima, Poaceae, and Solanaceae) and high percentages of Cucurbitaceae and Zea, both taxa characteristic of croplands (Figure 2). These samples cover a broad altitudinal gradient (from 0 to $1200 \mathrm{~m}$ a.s.l.) and sites near to urban centers, roads, and farming areas (e.g., Amatitlán, El Espino, and Jucutuma) (Figure 2). Samples from seasonal vegetation (scrubs, deciduous, and semi-deciduous forests) do not differ in their pollen spectra, so are grouped as tropical seasonal forest (TSF). This group has the largest sample size, with 51 locations from lowlands and mountain depressions, and its pollen spectra is dominated by Acacia, Bursera, Vitex, and Mimosa. Pollen assemblages from locations classified as tropical evergreen forest (TEF), under 800 m a.s.l. (e.g., Yaxhá, Macanché, and Sacpuy), are dominated by Brosimum, Ficus, Trema, Moraceae, and Melastomataceae (Figure 2).

Values of HII for the studied locations vary from 4 and 7 at the most preserved locations (Cobá and Chacan-Bata), to 43 and 48 at the most impacted localities (Calderas and El Espino). The higher values of HII are found at CP locations (26.3 in average), followed by CQF (21.8 in average), and 

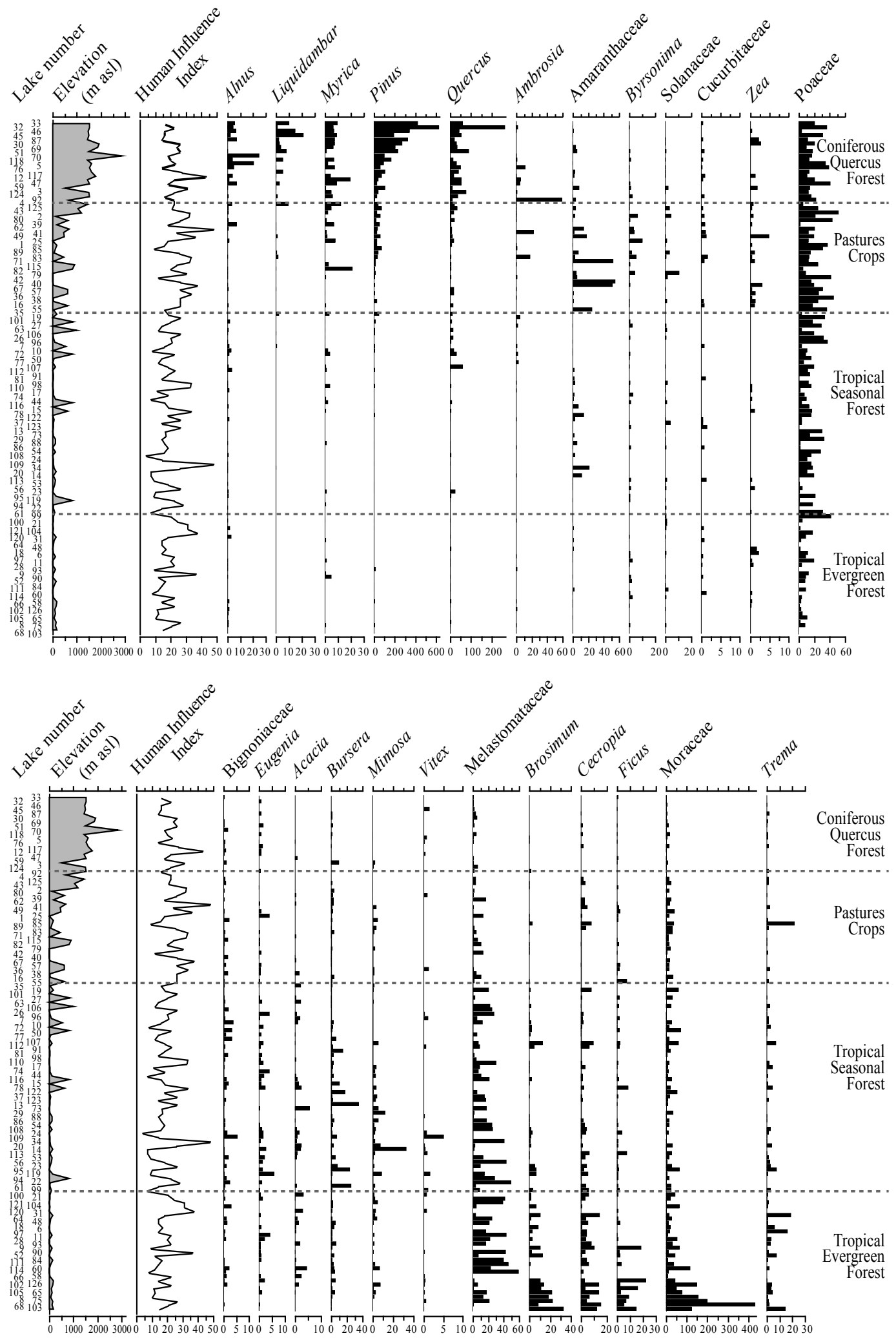

Figure 2 Pollen percentage diagram of mud-water interface samples from 125 lakes. Selected pollen taxa with at minimum presence of $1 \%$ in at least five samples are shown. Taxa were arranged according to their scores of Detrended Correspondence Analysis, while samples were organized according to the vegetation type of the area where the sample was recovered. 
lastly, TEF and TSF obtain similar HII (18 in average; Figure 2).

DCA scores produce a split of vegetation types along Axis 1 (eigenvalue 0.51, axis length 2.92) and Axis 2 (eigenvalue 0.24, axis length 3.1) (Figure 3G). Liquidambar, Myrica, Pinus, and Quercus show positive scores, while Brosimum, Ficus, Melastoma- taceae, and Moraceae display negative scores. Elements that usually characterize disturbances, such as Amaranthaceae, Ambrosia, Poaceae, Solanaceae, and Zea, are associated with scores near zero. Results from DCA ordination for the sites show a clear separation of vegetation types along the first two axes (Figure 3D). Samples from CQF are
DCA Axis 1

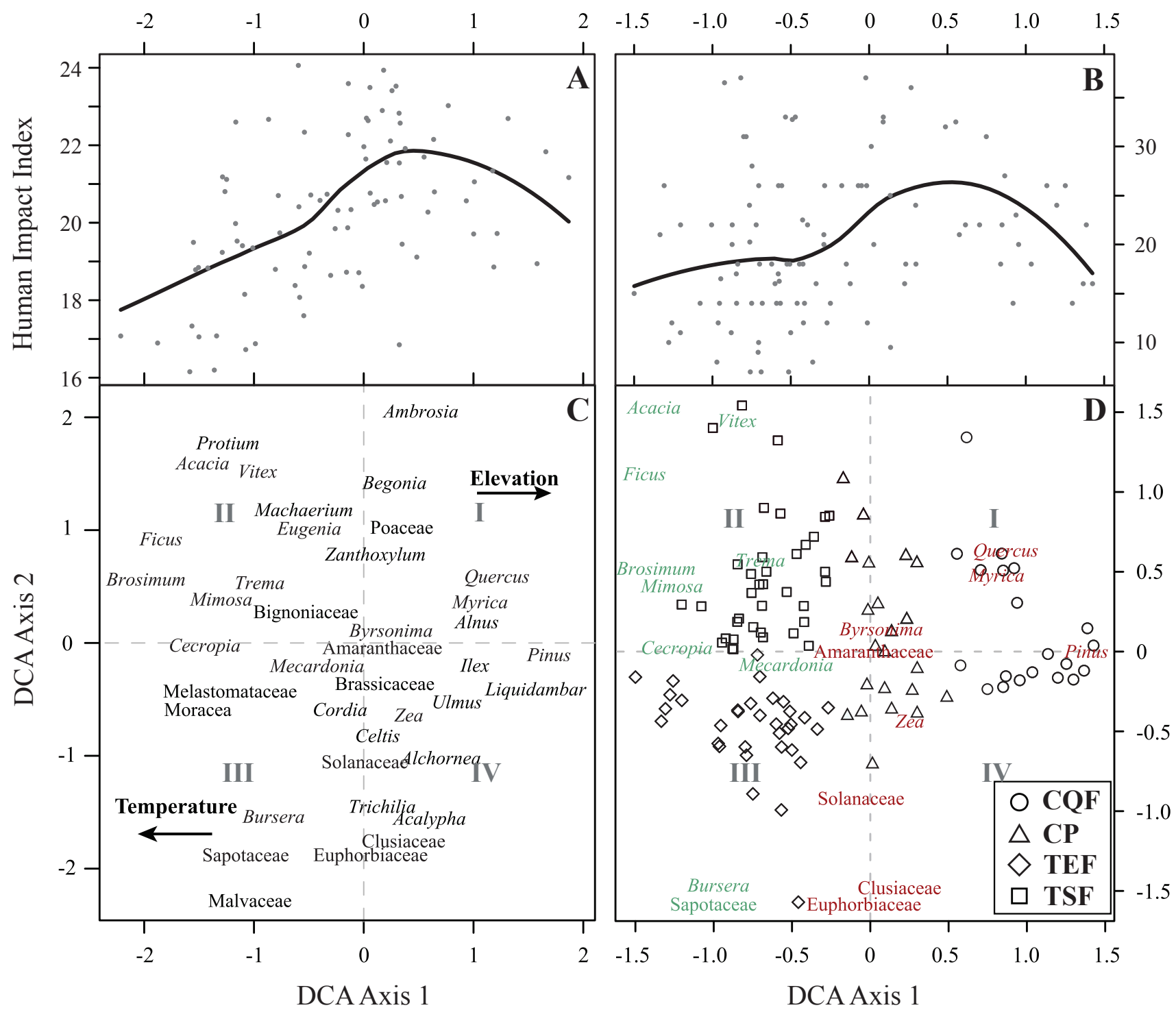

Figure 3 Detrended Correspondence Analysis (DCA) of modern pollen from Maya lands. A. Locally weighted non-parametric regression (loess) for human influence index as a function of DCA Axis 1 taxon scores. B. Loess regression for human influence index as a function of DCA Axis 1 sample scores. C. Ordination of taxa. D. Samples ordination with taxa selected from the Threshold Indicator Taxa analysis, negative (green) and positive (red) responses to the human influence CQF: Coniferous and Quercus forest; CP: croplands and pastures; TSF: tropical seasonal forest; TEF: tropical evergreen forest. 
clustered in the positive end (quadrants I and IV), while CP locations show a wide distribution along the central part of Axis 2. Samples from TSF and TEF are separate in the negative side (quadrants II and III, respectively).

A positive non-linear relationship between DCA Axis 1 taxa scores and their weighted HII is evident according to loess regression with low residual error standard (RSE, 2.3) (Figure 3A). Also, the loess analysis also suggests a breakpoint along the HII gradient between 20 and 22. The comparison between HII values and DCA Axis 1 scores per sites do not show a relationship with a loess-regression poorly adjusted $(\mathrm{RSE}=8.3)($ Figure $3 \mathrm{~B})$.

\subsection{THRESHOLD INDIGATOR TAXA ANALYSIS}

The spatial resampling and the presence/persistence filter generate a reduced dataset composed of 112 samples and 76 pollen taxa. Through taxa indicators analysis, 20 of the 76 taxa are identified as pure or reliable indicators of human impact (Figure 4A). Negative responses (Z-) to HII are found for Mimosa, Vitex, Bursera, Ficus, Sapotaceae, Brosimum, Trema, and Cecropia, which show lower occurrence and abundance along a short length of human-influence gradient (average $=11)$. Eugenia, Mecardonia, and Acacia also decrease as HII increases but alonga wider length of gradient (average $=29$ ). Nine taxa show positive responses to HII. Among them, Zea, Byrsonima, Pinus, and Myrica respond along short sections of the human-impact gradient (average $=13$ ), while Solonaceae, Euphorbiaceae, Clusiaceae, Amaranthaceae, and Quercus do so along a wider gradient (average $=$ 25).

About the community responses along the human-influence gradient, the summation of Z-scores $(\operatorname{sum}(Z))$ indicate a change-point at HII = $15\left(5^{\text {th }}, 95^{\text {th }}\right.$ quantiles of $\mathrm{HII}=12,20$, respectively), having a sharp, well-defined peak in $\operatorname{sum}(Z-)$ scores (Figure 4B). Except for Mimosa, Vitex, Eugenia, and Cecropia, where significant Z- taxa have points changes outside the threshold. The sum $(\mathrm{Z}+)$ scores show a change-point at HII $=24\left(5^{\text {th }}\right.$, $95^{\text {th }}$ quantiles of $\mathrm{HII}=14,30$, respectively), but

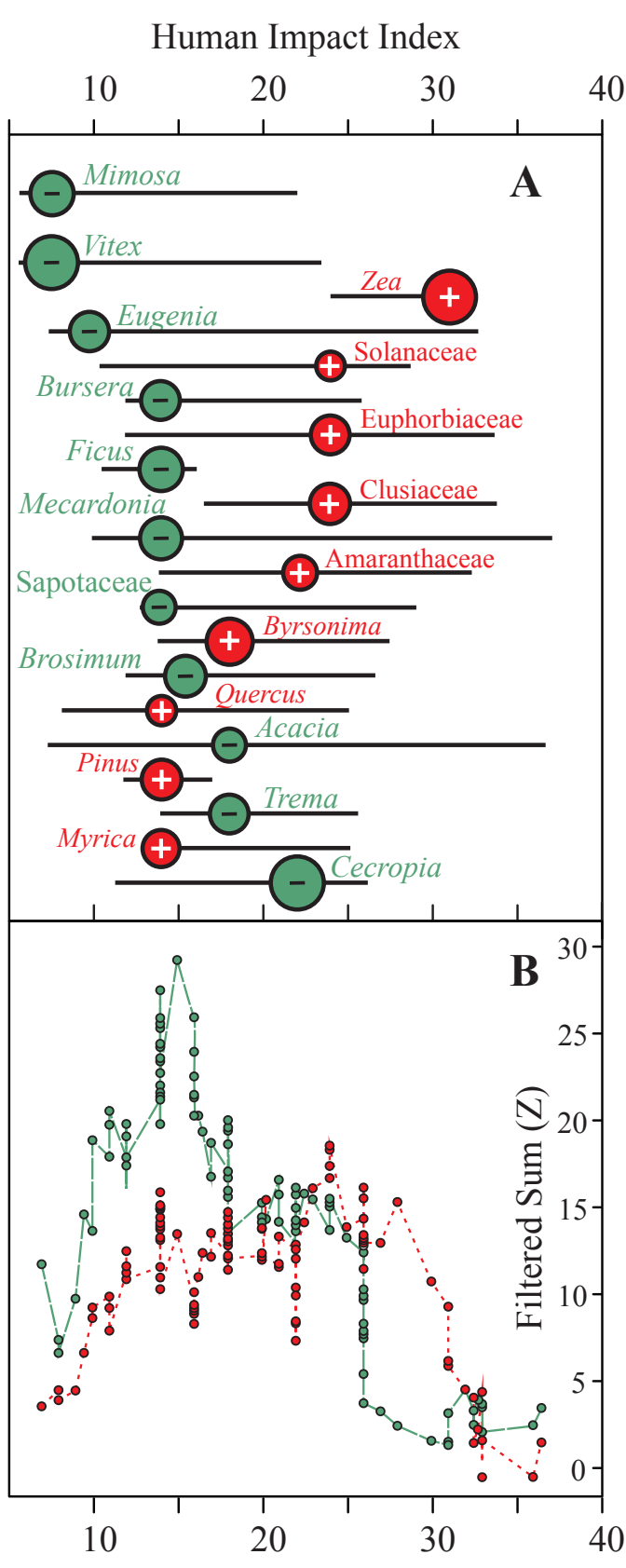

Human Impact Index

Figure 4 Threshold Indicator Taxa Analysis. A. Inflection points $\left(5^{\text {th }}, 95^{\text {th }}\right.$ bootstrap quantile intervals) for significant pollen taxa along human influence gradient. Significant indicator pollen are taxa with IndVal $\mathbf{p}<0.05$, purity is greater than 0.90 and reliability is greater than 0.95 for 1000 bootstrap and 250 permutation replicates. Green and red circles represent change points associated with negative and positive responses, respectively. Note that $Z$ scores are sized proportional to the magnitude of the response. $B$. Community changes for pollen taxa. Summation of individual taxon responses represented by $\mathrm{Z}$ - and $\mathrm{Z}+$ scores. 
it is not considered a threshold response because of wide quantiles and poorly defined peaks in sum $(\mathrm{Z}+)$ (Figure 4B). Few taxa have well-defined synchronous change-points along the human-influence gradient (Figure 4A), indicating gradual changes in sum $(\mathrm{Z}+)$ scores with HII between 14 and 30 .

\section{Discussion}

\subsection{MODERN POLLEN SIGNAL}

Modern pollen assemblages are highly sensitive to local vegetation types, as previously reported for the Maya lands (e.g. Islebe et al., 2001; Domínguez-Vásquez et al., 2004; Bhattacharya et al., 201 1; Correa-Metrio et al., 2011). However, although vegetation of the studied region is represented by at least 10 different vegetation types, our pollen spectrum distinguishes four main associations: CQF, TSF, TEF, and CP (Figure 2). Human-induced vegetation such as croplands and pastures are widely distributed in the region, simplifying vegetation and diversity, and therefore blurring the ability of pollen to distinguish more-specific vegetation associations. Nevertheless, the low taxonomic resolution of pollen analysis is likely a structural problem to distinguish among vegetation types (Correa-Metrio et al., 2011). In the lowlands, the pollen signal might be masked by genera shared by different forest types that are not distinguishable at the species level. In the mid-elevation and highlands, anemophilous taxa that have been widely recognized as problematic (e.g. Lozano-Garcia and Xelhuantzi-López, 1997; Correa-Metrio et al., 2011; Correa-Metrio et al., 2012b) cause further masking of the pollen signal. Although a pollen-based, clear-cut distinction of forest types according to modern vegetation is not possible, the pollen signal reflects the continuous nature of the realized biological and environmental gradients.

Our results also produce a clear distinction of CP assemblages dominated by non-arboreal taxa such as Ambrosia, Amaranthaceae, Solanaceae, Zea, and Poaceae, a finding previously reported for the region (Bhattacharya et al., 2011; Correa-Metrio et al., 2011). These taxa are also commonly found in large numbers within the CQF locations, which would suggest an important component of human-impacted vegetation within these areas. Nevertheless, CQF enrichment of these elements is probably also the result of the environmental hardships that vegetation experiences at high elevations through the entire year.

\subsection{POLLEN ASSEMBLAGES OF THE MAYA LANDS: EGOLOGICAL AND HUMAN SIGNALS AT ASSEMBLAGE LEVEL}

The DCA Axis 1 shows a clear separation of TEF and TSF on its negative side, while CQF is clustered towards the positive end (Figure 3D). Thus, DCA Axis 1 clearly reflects a temperature gradient, a finding previously reported for Central America and the Maya lowlands (e.g. Bush and Colinvaux, 1990; Correa-Metrio et al., 201 1; Correa-Metrio et al., 2012a). CP samples obtained scores near zero in the DCA Axis 1 (Figure 3D), although they are not necessarily coming from intermediate temperatures. According to the loess regression, the relationship between pollen assemblages and HII values show a non-linear pattern. This is explained because taxa associated with the highest HII are arranged towards the center of Axis 1. Therefore, is probably the result of cosmopolitan taxa (e.g., Amaranthaceae, Ambrosia, Asteraceae, and Poaceae) acting as a gravity center of the ordination and therefore representing the transition between contrasting environments, in this case from lowlands to highlands (Figure 3G). Indeed, this transition zone likely reflects a simplifying effect of people on the landscape (Caballero-Rodríguez et al., 2017), explaining the changes from complex tropical ecosystems to most simple temperate ecosystems in terms of its structure.

On quadrants II and III of the DCA, Axis 2 produces a clear separation of lowland systems into TEF (negative scores) and TSF (positive scores) (Figure 3D), implying a seasonality gradient previ- 
ously reported for the region (Correa-Metrio et al., 2011; Correa-Metrio et al., 2012a). At the center and the positive end of Axis 1, however, CP and CQF samples are widely distributed along Axis 2. This finding reflects two independent factors on these pollen spectra groups: (i) the widespread distribution of CP samples along the region in terms of the seasonality gradient, and therefore the lack of association of HII with DCA Axis 2; and (ii) the lack of a clear precipitation seasonality gradient along the CQF sampled sites (Figure 3D).

Although the temperature/elevation gradient led the DCA ordination, there is a signal of human influence in the vegetation suggested by the significant correlation between Axis 1 taxa scores and their weighted HII (Figure 3A). However, loess regression on HII data as a function of Axis 1 site scores produced by the DCA does not show a pattern as clear as that of the scores of taxa (Figure 3B). Thus, pollen spectra reflect human influence on vegetation through a taxon approach, and the assemblage signal is rather weak.

\subsection{HUMAN INFLUENGE INDICATION AT TAXON LEVEL}

The threshold-indicator taxa analysis allows the identification of 20 pollen taxa whose presence and abundance are significantly associated with human influence (Figure 4A). Most of the elements that show a decreasing response to HII are arboreal and their distribution is confined to the lower end of the impact gradient (Figure 4A). The inflection point in the response of these elements is found below HII = 20, except for Cecropia (Figure 4A). According to the DCA, Mimosa, Vitex, Eugenia, Ficus, Brosimum, Acacia, and Trema, all negative responders to HII, are associated with TSF (Figure 3D). Alternatively, only Bursera and Sapotaceae are associated with TEF, pointing to the dominance of negative responders in the TSF and suggesting a high sensibility of these ecosystems to human impact. These forests are established mostly in the lowlands from the Yucatan Peninsula, where high seasonality probably potentiates the effects of human activities. Conversely, more stable cli- mates through the year at the TEF locations might buffer human impact. Cecropia and Mecardonia do not show a clear grouping with a single vegetation type, but they are arranged at the TSF-TEF transition. Specifically Cecropia, a taxa widely recognized as a component of secondary forests (Rzedowski, 2006; Bhattacharya et al., 2011), shows a negative response along HII gradient. This apparent discrepancy might indicate that, albeit tolerant to certain disturbance levels, this taxon is affected when the human impact gets intensified. Indeed, the inflection point of its response to HII is found at a rather high value (22, Figure $4 \mathrm{~A})$.

Taxa with positive responses to human influence are characterized by both non-arboreal and arboreal elements, and spread along a substantial portion of the studied HII gradient (Figure 4A). Zea, Solanaceae, Euphorbiaceae, Clusiaceae, Amaranthaceae, and Byrsonima are distributed along mid to high HII indexes, and according to the DCA are mostly associated with CP locations (Figure 3D). However, their central location on DCA Axis 1 suggests that they can be found in any vegetation association. These elements have been reported as disturbance indicators in modern and fossil pollen studies from Central America (Wahl et al., 2006; Bhattacharya et al., 2011; Correa-Metrio et al., 2011). Myrica, Pinus, Quercus and Byrsonima, all arboreal to shrub elements from CQF (Figure 3D), show increases at low to moderate levels of human influence. Low intensity anthropogenic activities such as agroforestry systems, particularly in montane areas, can generate patchy open habitats, which can be rapidly colonized by opportunistic taxa (Cayuela et al., 2006). However, Pinus and Quercus should be interpreted with caution because they are high pollen producers and long-distance dispersers (Mazier et al., 2006; Correa-Metrio et al., 2011), implying a significant regional input that may not necessarily reflect local conditions. Other taxa commonly identified as indicators of disturbance, such as Ambrosia, Asteraceae, Celtis, and Poaceae (Pohl et al., 1996; Bush, 2002; Correa-Metrio et al., 2011), are not identified as significantly responding to human impact. However, 
they are clustered near the origin of DCA Axis 1 (Figure $3 \mathrm{C}$ ), a region that our loess regressions identified as of maximum HII for both taxa and sites. The lack of significant response to the HII gradient through the threshold-indicator taxa analysis might be a result of their cosmopolitan distribution (Marchant et al., 2002). Their association with human impact might be better reflected by their abundances than by their occurrence along the studied sites, and both attributes are taken into account by the method used.

\subsection{THRESHOLD IDENTIFICATION}

The summation of $\mathrm{Z}$ values to evaluate community-level responses show a substantial decline around HII = 15 (Figure 4B), suggesting almost synchronous response of all taxa that decline with the human impact. Responses to human disturbance of forests, insects, and lake biological communities showed similar thresholds for low and intermediate disturbance levels (Cardoso et al., 2013; Kovalenko et al., 2014; Rodrigues et al., 2016). It is likely that once the level of human pressure exceeds a given threshold, important elements of forest cover are affected simultaneously, benefiting opportunistic species. Although we detected 7 of 11 taxa with thresholds near HII $=15$, the uncertainty at the community level is rather high, pointing at the individual response of biological populations to disturbance. Thus, there is not a single threshold that explains the response of the entire community, but instead there might be a common level where the risk of taxa loss is high. On the other hand, asynchrony among positive responders is evidenced in the several change points (at 14, 18, 24, and 26 HII values) along the human-influence gradient, which produce a relatively weak aggregate signal of community response (Figure 4B). It is possible that the occupation of these taxa in human-disturbed areas depends on more complex factors; for example, the temporal structure of the disturbance.

\section{Conclusions}

The main vegetation associations of the Maya lands (CQF, CP, TSF, and TEF) are identifiable through the study of their associated pollen spectra. They show a clear separation in the DCA ordination, and their distribution along the two first axes show climatic and anthropogenic influence gradients. TEF and CP are clearly distinguishable by their respective pollen assemblages, while vegetation associations within $\mathrm{TSF}$ and $\mathrm{CQF}$ are rather difficult to identify. The lack of distinction into more vegetation units is likely the result of three factors: (i) the generalized human impact along the study area and subsequent simplification of the natural vegetation, (ii) the low taxonomic resolution in the pollen analysis, and (iii) the continuous nature of the realized biological and environmental gradients.

Our study suggests that responses of modern pollen to human-influence gradient at taxon-specific levels are more significant than at the community level. Twenty pollen taxa are significantly related to human influence, although they are representative of different vegetation associations. Arboreal elements from tropical seasonal forests show a decreasing response to HII, indicating the high sensitivity of these areas to human influence. In contrast, only two taxa from tropical evergreen forests are negative responders to HII, suggesting these forests are more resilient to human impact. Most taxa that show a positive response to HII are non-arboreal, and they dominate in samples from croplands and pastures. Overall, our findings provide useful tools for interpreting the paleoecological record based on the study of taxon responses to human impact.

The threshold analysis allows the identification of a community-level threshold of human impact. When human influence exceeds a threshold of 15, important elements of the vegetation are negatively affected simultaneously, allowing the dominance of taxa with affinity and/or tolerance to human 
disturbances. This finding highlights the importance of continuing to protect natural areas from human activities, because according to our results, incipient human-impact levels lead to important losses of forest structure. Indeed, forests that continuously experience environmental hardship are the most sensitive to human activities. Particularly in areas such as the Maya region, where for thousands of years a large number of sites have been subject to different levels of anthropogenic stress.

\section{Acknowledgements}

F.F-G., D.C-R., and A.C-M. were funded by grants PAPIIT-UNAM IN107716 and CONACYT 256406; L.P. was funded by grants PAPIIT-UNAM IA100317 and CONACYT 252148; A.S., S.C., and L.M-G. were funded by grant Deutsche Forschungsgemeinschaft SCHW 671/16-1. We appreciate the help of all colleagues and institutions involved in this work. Special thanks to the student team from the Instituto Tecnológico de Chetumal, Centro Interdisciplinario de Ciencias Marinas, and Universidad Autónoma de San Luis Potosí for their help in field. We would like to thank the following colleagues and institutions: Manuel Elías (El Colegio de la Frontera Sur, Chetumal Unit, Mexico); Alexis Oliva and the team from the Asociación de Municipios del Lago de Yojoa y su Área de Influencia (AMUPROLAGO, Honduras); María Renée Álvarez, Margarita Palmieri, Eleonor de Tott, and Roberto Moreno (Universidad del Valle de Guatemala, Guatemala); Consejo Nacional de Áreas Protegidas (CONAP, Guatemala); Néstor Herrera; and Ministerio de Medio Ambiente (San Salvador, El Salvador).

\section{References}

Baker, M.E., King, R.S., 2010, A new method for detecting and interpreting biodiversity and ecological community thresholds: Methods in Ecology and Evolution, 1, 25-37.
Baker, M.E., King, R.S., 2013. Of TITAN and straw men: an appeal for greater understanding of community data. Freshwater Science 32, 489-506.

Beach, T., Dunning, N., Luzzadder-Beach, S., Cook, D.E., Lohse, J., 2006. Impacts of the ancient Maya on soils and soil erosion in the central Maya Lowlands. CATENA 65, 166-178.

Bhattacharya, T., Beach, T., Wahl, D., 2011. An analysis of modern pollen rain from the Maya lowlands of northern Belize. Review of Palaeobotany \& Palynology 164, 109-120.

Birks, H.J.B., Gordon, A.D., 1985. Numerical Methods in Quaternary Pollen Analysis. Academic Press, London, 317 pp.

Brun, C., 2011. Anthropogenic indicators in pollen diagrams in eastern France: a critical review. Vegetation History and Archaeobotany 20, 135-142.

Bush, M.B., 2002. On the interpretation of fossil Poaceae pollen in the lowland humid neotropics. Palaeogeography, Palaeoclimatology, Palaeoecology 177, 5-17.

Bush, M.B., Colinvaux, P.A., 1990. A pollen record of a complete glacial cycle from lowland Panama. Journal of Vegetation Science 1, 105-119.

Caballero-Rodríguez, D., Lozano-García, S., Correa-Metrio, A., 2017. Vegetation assemblages of central Mexico through the late Quaternary: modern analogs and compositional turnover. Journal of Vegetation Science 28, 504-514.

Cardoso, P., Rigal, F., Fattorini, S., Terzopoulou, S., Borges, P.A.V., 2013. Integrating Landscape Disturbance and Indicator Species in Conservation Studies. PLoS ONE 8, e63294.

Cayuela, L., Golicher, J., Rey Benayas, J.M., González-Espinosa, M., Ramírez-Marcial, N., 2006. Fragmentation, disturbance and tree diversity conservation in tropical montane forests. Journal of Applied Ecology 43, 1172-1181. 
Cleveland, W.S., Devlin, S.J., 1988, Locally weighted regression: An approach to regression analysis by local fitting: Journal of the American Statistical Association, 83, 596-610.

Correa-Metrio, A., Bush, M.B., Cabrera, K.R., Sully, S., Brenner, M., Hodell, D.A., Escobar, J., Guilderson, T., 2012a, Rapid climate change and no-analog vegetation in lowland Central America during the last 86000 years: Quaternary Science Reviews, 38, 63-75.

Correa-Metrio, A., Bush, M.B., Pérez, L., Schwalb, A., Cabrera, K.R., 2011, Pollen distribution along climatic and biogeographic gradients in northern Central America: The Holocene, 21, 681-692.

Correa-Metrio, A., Cabrera, K.R., Bush, M.B., 2010, Quantifying ecological change through Discriminant Analysis: a paleoecological example from the Peruvian Amazon: Journal of Vegetation Science, 21, 695-704.

Correa-Metrio, A., Dechnik, Y., Lozano-García, M.S., Caballero, M., 2014, Detrended correspondence analysis: A useful tool to quantify ecological change from fossil data sets: Boletín de la Sociedad Geológica Mexicana, 66, 135-143.

Correa-Metrio, A., Lozano-Garcia, M.S., Xeltzuantzi, S., Sosa-Najera, M.S., 2012b, Vegetation in western central Mexico during the last 50000 years: modern analogs and climate in Zacapu Basin: Journal of Quaternary Science, 27, 509-518.

Dearing, J.A., 2006, Climate-human-environment interactions: resolving our past: Climate of the Past, 2, 187-203.

Delcourt, H.R., Delcourt, P.A., 1991, Quaternary Ecology: A paleoecological perspective. Chapman \& Hall, Cornwall, UK, 242 pp.

Domínguez-Vásquez, G., Islebe, G.A., Villanueva-Gutiérrez, R., 2004, Modern pollen deposition in Lacandon forest,
Chiapas, Mexico. Review of Palaeobotany \& Palynology, 131, 105-116.

Dufrene, M., Legendre, P., 1997, Species assemblages and indicator species: the need for a flexible asymmetrical approach: Ecological monographs, 67, 345-366.

Ford, A., Nigh, R., 2009, Origins of the Maya Forest Garden: Maya resource management: Journal of Ethnobiology, 29, 213-236.

Hill, M.O., Gauch, H.G., 1980, Detrended correspondence analysis: an improved ordination technique: Vegetation, 42, 41-58.

Islebe, G.A., Villanueva-Gutiérrez, R., SánchezSánchez, O., 2001, Relación lluvia de pollenvegetación en Selvas de Quinatan Roo: Boletín de la Sociedad Botánica de México, 69, 29-36.

Kovalenko, K.E., Brady, V.J., Brown, T.N., Ciborowski, J.J.H., Danz, N.P., Gathman, J.P., Host, G.E., Howe, R.W., Johnson, L.B., Niemi, G.J., Reavie, E.D., 2014, Congruence of community thresholds in response to anthropogenic stress in Great Lakes coastal wetlands: Freshwater Science, 33, 958-971.

Leyden, B.W., 1987, Man and climate in the Maya lowlands: Quaternary Research, 28, 407-414.

Loveland, T.R., Reed, B.C., Brown, J.F., Ohlen, D.O., Zhu, Z., Yang, L., Merchant, J.W., 2000, Development of a global land cover characteristics database and IGBP Discover from $1 \mathrm{~km}$ AVHRR data: International Journal of Remote Sensing, 21, 1303-1330.

Lozano-Garcia, M.S., Xelhuantzi-López, M.S., 1997, Some problems with the late Quaternary pollen records of Central Mexico: Basins of Mexico and Zacapu: Quaternary International, 43/44, 117-123.

Magaña, V.O., Vázquez, J.L., Pérez, J.L., Pérez, J.B., 2003, Impact of El Niño on precipitation in Mexico: Geofísica Internacional, 42, 313-330. 
Marchant, R., Almeida, L., Behling, H., Berrio, J.C., Bush, M., Cleef, A., Duivenvoorden, J., Kappelle, M., de Oliveira, P., de Oliveira-Filho, A.T., Lozano-Garcia, S., Hooghiemstra, H., Ledru, M.-P., LudlowWiechers, B., Markgraf, V., Mancini, V., Paez, M., Preto, A., Rangel, O., SalgadoLabouriau, M.L., 2002, Distribution and ecology of parent taxa of pollen lodged within the Latin American Pollen Database: Review of Palaeobotany and Palynology, $121,1-75$.

Mazier, F., Galop, D., Brun, C., Buttler, A., 2006, Modern pollen assemblages from grazed vegetation in the western Pyrenees, France: a numerical tool for more precise reconstruction of past cultural landscapes: The Holocene, 16, 91-103.

Méndez, M., Magaña, V., 2010, Regional Aspects of Prolonged Meteorological Droughts over Mexico and Central America: Journal of Climate, 23, 1175-1188.

Nigh, R., Diemont, S.A.W., 2013, The Maya Milpa: fire and the legacy of living soil: Frontiers in Ecology and the Environment, $11,45-54$.

Nixon, K.C., 2006, Global and neotropical distribution and diversity of oak (genus Quercus) and oak forests, in Kapppelle, M. (ed.), Ecology and conservation of neotropical montane oak forests: Springer, Berlin Heidelberg, 4-13.

Oksanen, J., Blanchet, G., Kindt, R., Legendre, P., O’Hara, B., Simpson, G.L., Solymos, P., Stevens, M.H.H., Wagner, H., 2017, Vegan: Community Ecology Package, 2.4-3 ed. The R Project for Statistical Computing, available at <http://CRAN.R-project.org/ package $=$ vegan $>$.

Palka, J.W., 2009, Historical Archaeology of Indigenous Culture Change in Mesoamerica: Journal of Archaeological Research, 17, 297-346.

Piperno, D.R., 1998, Paleoethnobotany in the Neotropics from Microfossils: New Insights into Ancient Plant Use and Agricultural Origins in the Tropical Forest: Journal of World Prehistory, 12, 393.

Piperno, D.R., 2006, Quaternary environmental history and agricultural impact on vegetation in Central America: Annals of the Missouri Botanical Garden, 93, 274-296.

Pohl, M.D., Pope, K.O., Jones, J.G., Jacob, J.S., Piperno, D.R., deFrance, S.D., Lentz, D.L., Gifford, J.A., Danforth, M.E., Josserand, J.K., 1996, Early Agriculture in the Maya Lowlands: Latin American Antiquity, 7, 355-372.

Quintana-Ascencio, P.F., Gonzalez-Espinosa, M., Ramirez-Marcial, N., Dominguez-Vazquez, G., Martinez-Ico, M., 1996, Soil Seed Banks and Regeneration of Tropical Rain Forest from Milpa Fields at the Selva Lacandona, Chiapas, Mexico: Biotropica, 28, 192-209.

R Core Team, 2017, R: A Language and Environment for Statistical Computing: Vienna, Austria, R Foundation for Statistical Computing, available at <http://www.Rproject.org/>, consulted on January 12, 2017.

Rodrigues, M.E., de Oliveira Roque, F., Quintero, J.M.O., de Castro Pena, J.C., de Sousa, D.C., De Marco Junior, P., 2016, Nonlinear responses in damselfly community along a gradient of habitat loss in a savanna landscape: Biological Conservation, 194, 113-120.

Rzedowski, J., 2006, Vegetación de México, $1^{\text {ra }}$ Edición digital ed. Comisión Nacional para el Conocimiento y Uso de la Biodiversidad, México D.F., 504 pp.

Sanderson, E.W., Jaiteh, M., Levy, M.A., Redford, K.H., Wannebo, A.V., Woolmer, G., 2002, The Human Footprint and the Last of the Wild: The human footprint is a global map of human influence on the land surface, which suggests that human beings are stewards of nature, whether we like it or not: BioScience, 52, 891-904.

Sharer, R.J., Traxler, L.P., 2006, The Ancient Maya: Stanford University Press, 931 pp. 
Wahl, D., Byrne, R., Schreiner, T., Hansen, R., 2006, Holocene vegetation change in the northern Peten and its implications for Maya prehistory: Quaternary Research, 65, 380-389.
Wilson, E.M., 1980. Physical geography of the Yucatan Peninsula, in Moseley, E.H., Terry, E.D. (eds.), Yucatan: a world apart: The University of Alabama Press, Tuscaloosa, 5-40.

\section{Appendix 1. Sampled locations}

Table S1. Sampled locations (Correa-Metrio et al., 2011). Geographic location, altitude (m a.s.I.), and Human Influence Index (HII, Sanderson et al., 2012) per sample.

\begin{tabular}{|c|c|c|c|c|c|c|c|c|c|c|c|}
\hline $\begin{array}{c}\text { Lake } \\
\text { Number }\end{array}$ & Lake & Longitude & Latitude & Altitude & HII & $\begin{array}{c}\text { Lake } \\
\text { Number }\end{array}$ & Lake & Longitude & Latitude & Altitude & HII \\
\hline 1 & Almond Hill & -88.31 & 17.46 & 0 & 18 & 32 & 5 Lakes small & -91.69 & 16.15 & 1534 & 22 \\
\hline 2 & Amatitlán & -90.55 & 14.43 & 1191 & 32.5 & 33 & 5 Lakes Big & -91.68 & 16.11 & 1534 & 16 \\
\hline 3 & Apastepeque ${ }^{*}$ & -88.744836 & 13.692456 & 509 & 31 & 34 & Cobá & -87.74 & 20.5 & 12 & 4 \\
\hline 4 & Atescatempa & -89.69 & 14.22 & 686 & 22 & 35 & Colón 1 & -91.89 & 15.83 & 634 & 26 \\
\hline 5 & Atitlán & -91.16 & 14.73 & 1602 & 23 & 36 & Colón 2 & -91.89 & 15.83 & 634 & 26 \\
\hline 6 & Azul ${ }^{*}$ & -90.643306 & 18.645639 & 18 & 14 & 37 & Colón 3 & -91.9 & 15.83 & 630 & 33 \\
\hline 7 & Bacab & -88.36 & 17.56 & 15 & 20 & 38 & Colón 4 & -91.9 & 15.83 & 630 & 33 \\
\hline 8 & Bacalar & -88.39 & 18.67 & 23 & 36.5 & 39 & Colón 5 & -91.89 & 15.83 & 630 & 26 \\
\hline 9 & Bacalar $2^{*}$ & -88.381944 & 18.700775 & 4 & 31 & 40 & Crooked Tree & -88.53 & 17.78 & 2 & 12 \\
\hline 10 & Belize 1 & -88.97 & 17.24 & 80 & 21 & 41 & El Espino & -89.865214 & 13.952967 & 689 & 48 \\
\hline 11 & Belize 2 & -88.49 & 17.31 & 23 & 14 & 42 & El Muchacho ${ }^{*}$ & -90.191772 & 13.889181 & 3 & 30 \\
\hline 12 & Calderas ${ }^{*}$ & -90.591336 & 14.411714 & 1790 & 43 & 43 & El Pino ${ }^{*}$ & -90.394136 & 14.344714 & 1038 & 21 \\
\hline 13 & Camp $^{*}$ & -90.988675 & 18.037019 & 43 & 26 & 44 & Emiliano Zapata ${ }^{*}$ & -88.469056 & 19.196672 & 23 & 11 \\
\hline 14 & Candelaria & -91.05 & 18.18 & 37 & 48 & 45 & Escondido & -91.68 & 16.11 & 1515 & 16 \\
\hline 15 & Caobas ${ }^{*}$ & -89.10075 & 19.444389 & 126 & 7 & 46 & Esmeralda $^{*}$ & -91.728607 & 16.118065 & 1473 & 16 \\
\hline 16 & Cayucón & -90.98 & 18.04 & 42 & 26 & 47 & Gemelas & -91.64 & 16.09 & 1458 & 22 \\
\hline 17 & Celestún & -90.38 & 20.86 & 1 & 33 & 48 & Gloria 1 & -90.37 & 16.95 & 131 & 18 \\
\hline 18 & Cenote 14 & -88.38 & 18.23 & 10 & 17 & 49 & Guija & -89.55 & 14.25 & 452 & 24 \\
\hline 19 & Cenote Timul & -89.36 & 20.59 & 15 & 16 & 50 & Honey Camp 13 & -88.44 & 18.05 & 0 & 8 \\
\hline 20 & Cenote Yokdzonot & -88.73 & 20.71 & 28 & 14 & 51 & Ipala ${ }^{*}$ & -89.639447 & 14.557056 & 1495 & 26 \\
\hline 21 & Chacan-Bata & -89.17 & 19.19 & 95 & 7 & 52 & Ixlu & -89.69 & 16.97 & 129 & 16.5 \\
\hline 22 & Chacan-Lara & -89.09 & 18.48 & 132 & 9 & 53 & Jamolun & -89.5 & 19.47 & 133 & 7 \\
\hline 23 & Chacanbacab ${ }^{*}$ & -89.086889 & 18.477667 & 109 & 9 & 54 & Jobal & -90.11 & 18.7 & 116 & 14 \\
\hline 24 & Chacchoben ${ }^{*}$ & -88.181056 & 19.037186 & 6 & 18 & 55 & Jocotal $^{*}$ & -88.251858 & 13.337133 & 26 & 26 \\
\hline 25 & Chanmico ${ }^{*}$ & -89.354122 & 13.778572 & 477 & 36 & 56 & Juarez & -87.34 & 20.8 & 23 & 7 \\
\hline 26 & Chantzip ${ }^{*}$ & -91.570165 & 16.970147 & 1000 & 12 & 57 & Jucutuma ${ }^{*}$ & -87.902786 & 15.512269 & 27 & 37 \\
\hline 27 & Chencha & -89.88 & 20.69 & 10 & 26 & 58 & Kana $^{*}$ & -88.39543 & 19.5008 & 5 & 8 \\
\hline 28 & Chichancanab & -88.77 & 19.88 & 3 & 11 & 59 & Kichayil & -91.66 & 16.1 & 1530 & 18 \\
\hline 29 & Chihuol * & -89.612 & 20.63502 & 23 & 26 & 60 & La perdida $2{ }^{*}$ & -90.575683 & 18.0338 & 49 & 14 \\
\hline 30 & Chiligatoro * & -88.182981 & 14.3756 & 1925 & 26 & 61 & Lacandón & -91.589797 & 17.015444 & 812 & 22 \\
\hline 31 & Chuina ${ }^{*}$ & -90.712728 & 18.961433 & 17 & 31 & 62 & Lachuá & -90.673197 & 15.918378 & 170 & 18 \\
\hline
\end{tabular}


Table S1. (Continued) Sampled locations (Correa-Metrio et al., 2011). Geographic location, altitude (m a.s.I.), and Human Influence Index (HII, Sanderson et al., 2012) per sample.

\begin{tabular}{|c|c|c|c|c|c|}
\hline $\begin{array}{c}\text { Lake } \\
\text { Number }\end{array}$ & Lake & Longitude & Latitude & Altitude & HII \\
\hline 63 & Lago Amarillo & -91.596667 & 16.984117 & 859 & 20 \\
\hline 64 & Laguna Chan * & -90.210917 & 18.479639 & 67 & 14 \\
\hline 65 & Laguna Perdida & -90.21 & 17.07 & 76 & 11 \\
\hline 66 & Las Pozas & -90.17 & 16.34 & 154 & 22 \\
\hline 67 & Los negritos ${ }^{*}$ & -87.936975 & 13.28305 & 102 & 32 \\
\hline 68 & Macanche & -89.63 & 16.97 & 166 & 15 \\
\hline 69 & Madre vieja ${ }^{*}$ & -88.137622 & 14.356922 & 1866 & 24 \\
\hline 70 & Magdalena ${ }^{*}$ & -91.395619 & 15.542581 & 2863 & 18 \\
\hline 71 & Metapán ${ }^{*}$ & -89.465533 & 14.309436 & 450 & 33 \\
\hline 72 & Metzabok ${ }^{*}$ & -91.627778 & 17.120833 & 546 & 16 \\
\hline 73 & Miguel Hidalgo ${ }^{*}$ & -88.367389 & 18.785639 & 31 & 14 \\
\hline 74 & Milagros & -88.43 & 18.51 & 0 & 32.8 \\
\hline 75 & Misteriosa & -90.48 & 18.05 & 70 & 10 \\
\hline 76 & Montebello & -91.71 & 16.11 & 1539 & 14 \\
\hline 77 & Nahá 1 & -91.6 & 16.976217 & 829 & 22 \\
\hline 78 & Nahá 2 & -91.596564 & 16.979028 & 832 & 16 \\
\hline 79 & Nahá 3 & -91.589119 & 16.983333 & 835 & 20 \\
\hline 80 & Nohbec & -88.18 & 19.15 & 0 & 22.5 \\
\hline 81 & Ocotalito & -91.601728 & 16.944208 & 920 & 24 \\
\hline 82 & Olomega ${ }^{*}$ & -88.055075 & 13.307233 & 66 & 25 \\
\hline 83 & Ocom & -88.05 & 19.47 & 13 & 12 \\
\hline 84 & Oquevix & -89.74 & 16.66 & 157 & 16 \\
\hline 85 & Oxola & -89.24165 & 20.67823 & 18 & 17 \\
\hline 86 & Peñasquito * & -91.75222 & 16.1322 & 1454 & 14 \\
\hline 87 & Petén de Monos & -90.32 & 20.85 & 7 & 16.3 \\
\hline 88 & Petén Itzá 5 & -89.85 & 17.01 & 111 & 9.5 \\
\hline 89 & Petén Itzá M & -89.86 & 17.01 & 111 & 9.5 \\
\hline 90 & Petexbatun & -90.18 & 16.42 & 110 & 18 \\
\hline 91 & Pojoj & -91.67 & 16.1 & 1537 & 16 \\
\hline 92 & Progreso & -88.42 & 18.22 & 14 & 20 \\
\hline 93 & Punta Laguna & -87.64 & 20.65 & 2 & 10 \\
\hline
\end{tabular}

\begin{tabular}{|c|c|c|c|c|c|}
\hline $\begin{array}{c}\text { Lake } \\
\text { Number }\end{array}$ & Lake & Longitude & Latitude & Altitude & HII \\
\hline 94 & Río Cuba & -90.48 & 17.95 & 79 & 18 \\
\hline 95 & Río Guerrero & -90.73 & 19.21 & 4 & 26 \\
\hline 96 & Rosario & -90.16 & 16.53 & 115 & 22 \\
\hline 97 & Sabak-há ${ }^{*}$ & -89.5881 & 20.57997 & 18 & 18 \\
\hline 98 & Sabanita & -88.57 & 18.4 & 30 & 28 \\
\hline 99 & Sacalaca ${ }^{*}$ & -88.599703 & 20.066669 & 28 & 14 \\
\hline 100 & Sacnab ${ }^{*}$ & -89.372467 & 17.058261 & 170 & 18 \\
\hline 101 & Sacpuy & -90.02 & 16.98 & 122 & 12 \\
\hline 102 & Salpetén & -89.68 & 16.98 & 106 & 21 \\
\hline 103 & Salto grande ${ }^{*}$ & -91.120217 & 18.196956 & 30 & 24 \\
\hline 104 & San Diego & -90.42 & 16.92 & 135 & 26 \\
\hline 105 & San Francisco Kana & -90.12 & 20.86 & 6 & 14 \\
\hline 106 & San Francisco Mateos & -90.66 & 17.9 & 53 & 14 \\
\hline 107 & San José de la Montaña * & -89.012028 & 18.368694 & 118 & 16 \\
\hline 108 & San José Aguilar & -89.01 & 18.37 & 125 & 16 \\
\hline 109 & San Miguel $2 *$ & -88.99831 & 19.93465 & 32 & 14 \\
\hline 110 & Señor ${ }^{*}$ & -88.07748 & 19.87646 & 3 & 12 \\
\hline 111 & Sijil Noh ha ${ }^{*}$ & -88.05543 & 19.4731 & 0 & 12 \\
\hline 112 & Silvituc & -90.29 & 18.64 & 47 & 14 \\
\hline 113 & Tekom & -88.27 & 20.6 & 26 & 22 \\
\hline 114 & Ticamaya $^{*}$ & -87.889728 & 15.550606 & 17 & 32.5 \\
\hline 115 & Vallehermoso ${ }^{*}$ & -88.5216 & 19.17812 & 18 & 18 \\
\hline 116 & Verde $^{*}$ & -89.787175 & 13.891467 & 1609 & 27 \\
\hline 117 & Vuelta el agua ${ }^{*}$ & -91.77 & 16.147222 & 1454 & 20 \\
\hline 118 & Xbacab ${ }^{*}$ & -90.720156 & 18.939875 & 18 & 26 \\
\hline 119 & Xlacah & -89.6 & 21.09 & 9 & 37 \\
\hline 120 & Yaa'x ek & -88.42 & 20.62 & 29 & 20.3 \\
\hline 121 & Yalahau & -89.22 & 20.66 & 11 & 18 \\
\hline 122 & Yalahau 2 * & -89.217008 & 20.657072 & 2 & 18 \\
\hline 123 & Yalaluch & -91.66 & 16.09 & 1503 & 22 \\
\hline 124 & Yalaluch $2{ }^{*}$ & -91.646403 & 16.092628 & 1448 & 22 \\
\hline 125 & Yaxhá & -89.41 & 17.07 & 164 & 14 \\
\hline
\end{tabular}

* New pollen data 
Appendix 2. Taxa-specific results from Threshold Indicator Taxa Analysis

Table S2. Threshold Indicator Taxa Analysis at taxon level in response to human influence gradient in Maya lands.

\begin{tabular}{|c|c|c|c|c|c|c|c|c|c|}
\hline Taxon & Obs & $\mathbf{P}$ & $\mathbf{Z}$ score & 0.05 & 0.5 & 0.95 & Purity & Reliability & Response \\
\hline Acacia & 18 & 0.008 & 3.53 & 7.5 & 18 & 36.5 & 0.718 & 0.992 & Z- \\
\hline Acalypha & 9.25 & 0.128 & 1.12 & 9.25 & 18 & 34.5 & 0.71 & 0.606 & 0 \\
\hline Alchornea & 12 & 0.02 & 2.9 & 11.5 & 16 & 22.1 & 0.95 & 0.904 & 0 \\
\hline Alnus & 24 & 0.024 & 2.64 & 14 & 23.5 & 40 & 0.72 & 0.928 & 0 \\
\hline Alternanthera & 14 & 0.096 & 1.31 & 12 & 17.5 & 31 & 0.542 & 0.702 & 0 \\
\hline Amaranthaceae & 22.25 & 0.004 & 3.82 & 14 & 22.5 & 33.075 & 0.976 & 0.952 & Z+ \\
\hline Amaryllidaceae & 14 & 0.08 & 1.66 & 14 & 18.5 & 36.7625 & 0.504 & 0.68 & 0 \\
\hline Ambrosia & 20 & 0.04 & 1.94 & 14 & 21 & 32.875 & 0.824 & 0.788 & 0 \\
\hline Anacardiaceae & 14 & 0.012 & 2.83 & 12 & 14.25 & 36.75 & 0.6 & 0.594 & 0 \\
\hline Apocynaceae & 36.75 & 0.064 & 1.89 & 12 & 22 & 37.05 & 0.81 & 0.746 & 0 \\
\hline Arecaceae & 16 & 0.064 & 1.81 & 10 & 20 & 32.625 & 0.834 & 0.734 & 0 \\
\hline Asteraceae & 7.5 & 0.036 & 2.06 & 7 & 13 & 32.625 & 0.8 & 0.75 & 0 \\
\hline Begonia & 11 & 0.048 & 1.95 & 9.7125 & 17.5 & 34.5 & 0.832 & 0.764 & 0 \\
\hline Bignoniaceae & 36.75 & 0.16 & 1.07 & 9.5 & 16 & 36.75 & 0.546 & 0.706 & 0 \\
\hline Bombacaceae & 11 & 0.22 & 0.79 & 11.5 & 16 & 33 & 0.432 & 0.394 & 0 \\
\hline Borreria & 16 & 0.108 & 1.29 & 11 & 20.5 & 36.5125 & 0.798 & 0.658 & 0 \\
\hline Brassicaceae & 22 & 0.244 & 0.46 & 7.5 & 18 & 36.75 & 0.488 & 0.604 & 0 \\
\hline Brosimum & 15.5 & 0.004 & 4.24 & 12 & 16 & 26.5 & 0.996 & 0.994 & Z- \\
\hline Bursera & 14 & 0.004 & 4.02 & 12 & 14 & 26 & 0.846 & 0.968 & Z- \\
\hline Byrsonima & 18 & 0.004 & 4.98 & 14 & 17.5 & 28.025 & 0.996 & 0.994 & $Z+$ \\
\hline Caesalpinia & 24 & 0.184 & 0.84 & 14 & 26 & 37 & 0.718 & 0.538 & 0 \\
\hline Casuarina & 26 & 0.124 & 1.12 & 10.5 & 20.375 & 32.5 & 0.558 & 0.51 & 0 \\
\hline Cecropia & 22 & 0.004 & 5.44 & 11.475 & 22 & 26 & 1 & 1 & Z- \\
\hline Celtis & 33 & 0.008 & 2.88 & 9.25 & 32.25 & 36.5 & 0.804 & 0.942 & 0 \\
\hline Clethra & 27.5 & 0.196 & 1.12 & 12 & 22 & 29 & 0.694 & 0.49 & 0 \\
\hline Clusiaceae & 24 & 0.004 & 4.55 & 16.71875 & 24 & 34.5 & 0.984 & 0.952 & $Z+$ \\
\hline Convolvulacea & 11.5 & 0.028 & 2.07 & 8 & 11.5 & 30.5 & 0.786 & 0.692 & 0 \\
\hline Cordia & 31 & 0.008 & 3.62 & 12 & 27 & 33 & 0.906 & 0.9 & 0 \\
\hline Cucurbitaceae & 26 & 0.044 & 2.23 & 13 & 26 & 33 & 0.906 & 0.804 & 0 \\
\hline Eugenia & 9.75 & 0.004 & 3.98 & 7.5 & 10.5 & 32.625 & 0.894 & 0.994 & Z- \\
\hline Euphorbiaceae & 24 & 0.004 & 4.22 & 12 & 24.5 & 34.7625 & 0.97 & 0.958 & Z+ \\
\hline Fabaceae & 32.875 & 0.06 & 2.08 & 10.5 & 24 & 36.75 & 0.966 & 0.876 & 0 \\
\hline Ficus & 14 & 0.008 & 4.51 & 10.5 & 14 & 16 & 0.988 & 0.988 & Z- \\
\hline Guettarda & 24 & 0.008 & 3.24 & 7.475 & 23.5 & 26 & 0.974 & 0.944 & 0 \\
\hline Gustavia & 17.5 & 0.128 & 1.4 & 7.5 & 18 & 33 & 0.794 & 0.748 & 0 \\
\hline Hedyosmum & 14 & 0.116 & 1.29 & 14 & 18 & 25 & 0.614 & 0.49 & 0 \\
\hline Hymenaea & 18 & 0.028 & 2.53 & 9.5 & 16.375 & 36.25 & 0.836 & 0.882 & 0 \\
\hline Ilex & 18 & 0.04 & 2.26 & 11.5 & 18 & 26 & 0.868 & 0.822 & 0 \\
\hline
\end{tabular}


Table S2. (Continued) Threshold Indicator Taxa Analysis at taxon level in response to human influence gradient in Maya lands.

\begin{tabular}{|c|c|c|c|c|c|c|c|c|c|}
\hline Taxon & Obs & $\mathbf{P}$ & Z score & 0.05 & 0.5 & 0.95 & Purity & Reliability & Response \\
\hline Inga & 14 & 0.064 & 2.02 & 12 & 16.125 & 39.7625 & 0.73 & 0.622 & 0 \\
\hline Iresine & 10.5 & 0.148 & 1.01 & 8.5 & 20 & 37 & 0.518 & 0.81 & 0 \\
\hline Liquidambar & 14 & 0.02 & 3.19 & 13 & 16 & 33 & 0.99 & 0.932 & 0 \\
\hline Machaerium & 18 & 0.028 & 2.69 & 14 & 18 & 36.0125 & 0.802 & 0.87 & 0 \\
\hline Malpighiaceae & 24.5 & 0.02 & 2.86 & 12 & 24.75 & 36.75 & 0.944 & 0.906 & 0 \\
\hline Malvaceae & 36.25 & 0.196 & 0.79 & 10.5 & 20 & 31.55 & 0.38 & 0.53 & 0 \\
\hline Mecardonia & 14 & 0.004 & 4.35 & 10 & 15 & 37 & 0.622 & 0.95 & Z- \\
\hline Melastomataceae & 7.5 & 0.372 & 0.32 & 7.5 & 20.5625 & 36.75 & 0.502 & 0.666 & 0 \\
\hline Meliaceae & 23.5 & 0.02 & 2.64 & 7 & 23 & 40 & 0.86 & 0.884 & 0 \\
\hline Mimosa & 7.5 & 0.008 & 4.3 & 7.475 & 12 & 22 & 0.964 & 0.954 & Z- \\
\hline Moraceae & 26 & 0.08 & 1.69 & 12 & 22 & 36.75 & 0.846 & 0.752 & 0 \\
\hline Myrica & 14 & 0.004 & 4.16 & 14 & 16 & 25 & 0.952 & 0.972 & $\mathrm{Z}+$ \\
\hline Myrsine & 23.5 & 0.056 & 1.73 & 9.75 & 16.375 & 24 & 0.9 & 0.72 & 0 \\
\hline Myrtaceae & 18 & 0.004 & 4.24 & 11 & 18 & 20 & 0.962 & 0.942 & 0 \\
\hline Nymphaea & 26 & 0.212 & 0.77 & 7 & 16 & 26 & 0.546 & 0.582 & 0 \\
\hline Paullinia & 7.5 & 0.028 & 2.27 & 7 & 16.125 & 26 & 0.928 & 0.872 & 0 \\
\hline Pinus & 14 & 0.004 & 4.43 & 12 & 14 & 18 & 1 & 1 & $\mathrm{Z}+$ \\
\hline Piperaceae & 24 & 0.012 & 3.43 & 24 & 26 & 37 & 0.982 & 0.914 & 0 \\
\hline Poaceae & 14 & 0.012 & 3.17 & 12 & 16 & 24 & 0.962 & 0.898 & 0 \\
\hline Polygonum & 26.5 & 0.024 & 2.37 & 7.5 & 26 & 31.5 & 0.738 & 0.866 & 0 \\
\hline Protium & 14 & 0.032 & 2.28 & 10 & 20.8125 & 34.5 & 0.648 & 0.624 & 0 \\
\hline Psychotria & 22.25 & 0.004 & 3.81 & 16 & 23.5 & 32.25 & 0.942 & 0.922 & 0 \\
\hline Quercus & 14 & 0.004 & 3.22 & 8 & 16 & 26 & 0.938 & 0.966 & $\mathrm{Z}+$ \\
\hline Rubiaceae & 24 & 0.052 & 2.1 & 14 & 24 & 34.5 & 0.738 & 0.782 & 0 \\
\hline Rutaceae & 14 & 0.32 & 0.34 & 7 & 16.25 & 27.025 & 0.52 & 0.516 & 0 \\
\hline Sapindaceae & 18 & 0.108 & 1.49 & 8 & 18 & 37 & 0.77 & 0.672 & 0 \\
\hline Sapium & 16 & 0.076 & 1.96 & 10 & 18 & 27.05 & 0.646 & 0.798 & 0 \\
\hline Sapotaceae & 14 & 0.004 & 3.41 & 13 & 14 & 29 & 0.728 & 0.97 & Z- \\
\hline Serjania & 18 & 0.176 & 0.95 & 11 & 18 & 34.5125 & 0.696 & 0.538 & 0 \\
\hline Solanaceae & 24 & 0.008 & 3.18 & 10.5 & 24.5 & 29.5 & 0.97 & 0.96 & $\mathrm{Z}+$ \\
\hline Spondias & 14 & 0.012 & 3.39 & 8 & 14 & 23 & 0.896 & 0.896 & 0 \\
\hline Trema & 18 & 0.004 & 4.18 & 14 & 18 & 25.5 & 1 & 0.998 & Z- \\
\hline Trichilia & 14 & 0.12 & 1.34 & 11.5 & 18 & 34.5 & 0.452 & 0.758 & 0 \\
\hline Typha & 7.5 & 0.092 & 1.3 & 7 & 14.5 & 26 & 0.844 & 0.672 & 0 \\
\hline Ulmus & 18 & 0.016 & 2.78 & 17 & 21.5 & 37 & 0.962 & 0.868 & 0 \\
\hline Vitex & 7.5 & 0.008 & 5.32 & 7 & 9.25 & 23.525 & 0.964 & 0.982 & Z- \\
\hline Zanthoxylum & 26 & 0.076 & 1.87 & 11.975 & 22 & 31 & 0.602 & 0.794 & 0 \\
\hline Zea & 31 & 0.004 & 5.84 & 24 & 30.5 & 32 & 0.984 & 0.988 & $\mathrm{Z}+$ \\
\hline
\end{tabular}

